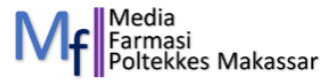

\title{
KADAR CEMARAN MERKURI (Hg) PADA DEODORAN PEMUTIH SECARA SPEKTROFOTOMETRI SERAPAN ATOM
}

\author{
Hj. Nurisyah ${ }^{1}$ \\ ${ }^{1}$ Jurusan Farmasi Poltekkes Kemenkes RI Makassar \\ *) E-mail korespondensi : nurisyah31@gmail.com
}

DOI: https://doi.org/10.32382/mf.v13i2.788

\section{ABSTRAK}

Telah dilakukan penelitian dengan tujuan untuk mengetahui ada tidaknya cemaran logam Hg dalam sampel deodoran yang beredar di Kota Makassar, serta untuk menentukan kadar cemaran logam Hg dalam sampel deodorant tersebut. Penelitian ini dilakukan di Laboratorium Kimia Jurusan Farmasi Politeknik Kesehatan Makassar pada bulan Agustus 2017. Sampel yang dianalisis adalah 3 merek deodorant bentuk roll-on yang beredar di Kota Makassar. Analisis kualitatif didasarkan pada adanya serapan hasil pengukuran larutan sampel dengan SSA yang kemudian dilanjutkan dengan menghitung kadar cemaran logam $\mathrm{Hg}$ tersebut berdasarkan besarnya serapan larutan sampel tersebut. Hasil analisis kualitatif terhadap ke 3 sampel tersebut menunjukkan hasil yang positif mengandung cemaran logam $\mathrm{Hg}$, dan kadar cemaran $\mathrm{Hg}$ rata-rata pada masing-masing sampel yang dianalisis adalah sampel A 0,02827 mg/kg, sampel B $0,03309 \mathrm{mg} / \mathrm{kg}$, sampel C $0,03067 \mathrm{mg} / \mathrm{kg}$. Dari hasil penelitian ini dapat disimpulkan bahwa kadar cemaran $\mathrm{Hg}$ dalam ke 3 sampel tersebut masih memenuhi syarat yang telah ditentukan yaitu tidak lebih dari $1 \mathrm{mg} / \mathrm{kg}$.

\section{Kata kunci : Cemaran, Hg, deodorant, Spektrofotometri Serapan Atom}

\section{PENDAHULUAN}

Hampir semua wanita ingin selalu tampil cantik dan menarik, sehingga segala upaya akan dilakukan dan salah satunya adalah menggunakan kosmetik, sehingga kosmetik menjadi kebutuhan pokoknya. Para produsen kosmetik akan selalu mempromosikan produknya dengan cara yang sangat menarik untuk memikat konsumennya, bahkan banyak wanita yang memilih atau memakai kosmetik tanpa memperhitungkan sisi kemanannya (Supriyadi, 2012).

Kosmetika adalah bahan atau sediaan yang dimaksudkan untuk digunakan pada bagian luar tubuh manusia (epidermis, rambut, kuku, bibir, dan organ genital bagian luar), atau gigi dan membran mukosa mulut, terutama untuk membersihkan, mewangikan, mengubah penampilan, dan/atau memperbaiki bau badan atau melindungi atau memelihara tubuh pada kondisi baik (BPOM, 2011).

Kosmetika dibuat dari campuran beberapa senyawa kimia yang dijadikan dalam bentuk sediaan fisik tertentu sesuai dengan yang diinginkan. Formulasi yang tidak tepat, penggunaan bahan yang tidak memenuhi persyaratan, serta adanya pencemaran pada sediaan dapat berakibat terjadinya efek samping yang merugikan sipemakai.Pada dasarnya sebelum kosmetika diproduksi dan diedarkan ke masyarakat harus dilakukan penilaian dan persetujuan dari Direktorat Pengawasan Kosmetika lewat pendaftaran produk jadi, sehingga setiap kosmetika harus dilengkapi dengan keterangan dan peringatan adanya efek samping yang mungkin terjadi. Meskipun demikian, karena pemakaian kosmetika di masyarakat juga semakin meningkat, sehingga membawa akibat efek samping juga semakin banyak (Sukanto, H. 2013).

Salah satu kosmetik yang banyak digunakan adalah deodoran. Deodoran adalah formula khusus yang diformulasikan untuk menyamarkan bau badan. Umumnya, deodoran mengandung antiseptik yang berguna untuk mencegah dekomposisi bakteri dengan membunuh dan menghambat pertumbuhan bakteri di permukaan kulit, khususnya di bagian ketiak. Deodoran bentuknya bermacam-macam, ada yang padat (stick), cairan roll-on, ada juga yang berbentuk spray. Kandungannya pun berbeda-beda. (Amin, Y.Z., 2010).

Ada juga beberapa deodoran yang mempromosikan produknya bisa memutihkan kulit ketiak. Produk seperti ini perlu diwaspadai, BPOM masih menemukan 
adanya produk-produk bermerkuri masih beredar di pasaran. Akumulasi merkuri dalam tubuh akan menyebabkan terjadinya degenerasi sel-sel saraf dan degenerasi sarung selaput saraf yang akhirnya bisa menyebabkan kelumpuhan dan kematian. Serangan juga terjadi pada bagian otak yang mengatur penglihatan berupa berkurangnya luas wilayah pandang (Amin, Y.Z., 2010).

Kosmetika yang diproduksi dan atau diedarkan harus memenuhi persyaratan keamanan, kemanfaatan dan mutu. Selain itu kosmetika juga harus memenuhi persyaratan cemaran mikroba dan logam berat. Cemaran Logam berat yang tersebut merupakan sesepora (trace element) yang tidak bisa dihindarkan. meliputi Merkuri, Timbal dan Arsen Dalam peraturan kepala Badan Pengawas Obat dan Makanan Republik Indoensia Nomor HK.03.1.23.07.11.6662 tahun 2011, disebutkan bahwa persyaratan cemaran merkuri dalam kosmetika tidak lebih dari $1 \mathrm{mg} / \mathrm{kg}$ atau $1 \mathrm{mg} / \mathrm{L}$ (1 ppm) (BPOM, 2011).

Salah satu parameter produk kosmetik dinyatakan tidak aman digunakan adalah adanya kandungan logam berat. Oleh karena pada umumnya kandungan logam berat yang nilainya kecil dalam suatu bahan sukar ditentukan keberadaannya dengan pereaksi-pereaksi kimia, tetapi dapat diketahui jumlah dan keberadaannya dengan spektrofotometri serapan atom ( Ginanjar, 2015).

Berdasarkan uraian di atas, maka demi keamanan penggunan maka perlu dilakukan uji terhadap produk deodoran yang dipromosikan yang dapat memutihkan kulit ketiak setelah digunakannya produk tersebut, khususnya terhadap keberadaan logam berat merkuri (Hg).

ini adalah :

Adapun rumusan masalah penelitian

1. Apakah deodoran pemutih yang beredar di Kota Makassar tercemar logam merkuri (Hg)?.

2. Berapakah kadar cemaran logam merkuri (Hg) dalam deodoran pemutih tersebut?

3. Apakah kadar cemaran logam merkuri tersebut memenuhi persyaratan, yaitu maksimal 1 ppm?
Adapun tujuan penelitian ini adalah :

1. Untuk mengetahui adanya cemaran logam merkuri $(\mathrm{Hg})$ pada deodoran yang digunakan sebagai pemutih

2. Untuk mengetahui kadar cemaran logam merkuri (Hg) dalam deodoran pemutih tersebut

3. Untuk mengetahui apakah cemaran logam merkuri $(\mathrm{Hg})$ tersebut memenuhi persyaratan, yaitu maksimal $1 \mathrm{ppm}$

\section{METODE DAN BAHAN}

\section{Jenis Penelitian}

Penelitian ini adalah penelitian observasi laboratorium yang dilakukan untuk mengetahui cemaran logam $\mathrm{Hg}$ dalam sampel deodorant yang beredar di Kota Makassar secara Spektrofotometri Serapan Atom

\section{Waktu dan Tempat Penelitian}

Penelitian ini telah dilakukan pada Agustus 2017, di Laboratorium Kimia Jurusan Farmasi Politeknik Kesehatan Makassar.

\section{Alat dan Bahan Yang Digunakan}

1. Alat yang digunakan dalam penelitian ini adalah : Timbangan analitik, alat-alat gelas laboratorium (labu ukur, gelas piala, mikroburet, pipet volum), lumpang dan Stamper, mikropipet, vial, aluminium foil, sikat tabung, dan spektrofotometer Serapan Atom.

2. Bahan yang digunakan dalam penelitian ini adalah: $\mathrm{HNO}_{3} 0,1 \mathrm{~N}, \mathrm{Hg}\left(\mathrm{NO}_{3}\right)_{2}$ p.a , sampel deodoran, air suling, kertas saring, etanol dan tissu.

\section{Pengambilan Sampel}

Sampel penelitian yang digunakan adalah 3 merek deodoran berbentuk roll on yang dipromosikan dapat memutihkan kulit ketiak, sampel diambil secara accindental sampling dari Supermaket di Kota Makassar.

\section{Prosedur Kerja}

\section{Pengolahan sampel}

Masing-masing sampel

dikeluarkan dari wadahnya, kemudian ditimbang saksama $10 \mathrm{~g}$ dan di masukkan ke dalam gelas piala $100 \mathrm{ml}$. Kemudian ditambahkan campuran $\mathrm{HNO}_{3}$ pekat dan $\mathrm{H}_{2} \mathrm{O}_{2}(2: 1)$ sebanyak $10 \mathrm{ml}$, dipanaskan perlahan-lahan di atas 
penangas listrik dalam lemari asam sampai tidak berasap. Kemudian larutan dipindahkan ke dalam labu ukur $50 \mathrm{~mL}$, dan dicukupkan volumenya dengan air suling hingga tanda.

\section{Pembuatan Larutan Baku $\mathrm{Hg}\left(\mathrm{NO}_{3}\right)_{2}$}

Ditimbang $\mathrm{Hg}\left(\mathrm{NO}_{3}\right)_{2}$ sebanyak $0,08 \mathrm{~g}$ dan dilarutkan dengan $\mathrm{HNO}_{3} 0,1 \mathrm{~N}$ hingga volumenya tepat $100,0 \mathrm{~mL}$ (diperoleh larutan dengan kadar $\mathrm{Hg} 500$ ppm). Kemudian diukur 1,0 mL larutan baku 500 ppm, dan diencerkan dengan $\mathrm{HNO}_{3} \quad 0,1 \mathrm{~N}$ hingga volumenya tepat $500,0 \mathrm{~mL}$ (diperoleh larutan dengan kadar Hg 1 ppm = 1000 ppb)

\section{Pembuatan kurva baku}

Dibuat sederet larutan baku $\mathrm{Hg}$ dengan konsentrasi $0 ; 10 ; 20 ; 30 ; 40$; dan $50 \mathrm{ppb}$ dengan cara diukur saksama masing-masing $0 ; 1,0 ; 2,0 ; 3,0 ; 4,0$; dan 5,0 mL larutan baku Hg 1000 ppm, dimasukkan ke dalam labu ukur $100 \mathrm{~mL}$ dan dicukupkan volumenya hingga tanda dengan $\mathrm{HNO}_{3} \quad 0,1 \mathrm{~N}$. diukur serapannya dengan SSA menggunakan lampu katoda
Hg pada panjang gelombang 253,7 nm, sebagai blanko digunakan larutan $\mathrm{HNO}_{3}$ $0,1 \mathrm{~N}$.

\section{Pengumpulan Data}

Pengukuran sampel larutan diukur serapannya dengan SSA menggunakan lampu katoda $\mathrm{Hg}$ pada panjang gelombang 253,7 nm. Data hasil pengukuran serapan blanko dan sampel dengan spektrofotometer serapan atom, dikumpulkan dan ditabulasikan.

\section{Analisis Data}

Data hasil pengukuran dihitung menggunakan persamaan garis regresi hasil pengukuran larutan standar.yaitu $\mathrm{y}=\mathrm{a}+\mathrm{bx}$.

\section{HASIL DAN PEMBAHASAN Hasil Penelitian}

Hasil analisis kadar cemaran merkuri (Hg) dalam 3 merek sampel deodoran pemutih berbentuk roll on dengan metode spektrofotometri serapan atom (SSA) menggunakan lampu katoda $\mathrm{Hg}$ pada panjang gelombang $253,7 \mathrm{~nm}$. dapat dilihat pada Tabel 1 di bawah ini :

Tabel 1. Hasil pengukuran serapan larutan sampel dengan SSA untuk menentukan keberadaan cemaran logam $\mathrm{Hg}$ dalam deodoran

\begin{tabular}{ccc}
\hline Sampel & Serapan & Kesimpulan \\
\hline A & $0,0562-0,0564$ & + \\
B & $0,0665-0,0684$ & + \\
C & $0,0613-0,0629$ & + \\
\hline
\end{tabular}

Keterangan:

A : sampel deodoran merek A

B : sampel deodoran merek B

C : sampel deodoran merek $\mathrm{C}$

$+\quad$ : mengandung cemaran $\mathrm{Hg}$
Tabel 1 di atas menunjukkan bahwa ke 3 sampel deodoran yang dianalisis positif mengandung cemaran logam $\mathrm{Hg}$.

Tabel 2. Kadar cemaran merkuri $(\mathrm{Hg})$ pada 3 sampel deodoran pemutih

\begin{tabular}{cccc}
\hline Sampel & Replikasi & $\begin{array}{c}\text { Kadar Hg } \\
(\mathrm{mg} / \mathrm{kg})\end{array}$ & $\begin{array}{c}\text { Kadar Hg } \\
\text { rata-rata }(\mathrm{mg} / \mathrm{kg})\end{array}$ \\
\hline \multirow{2}{*}{$\mathrm{A}$} & 1 & 0,02829 & \\
& 2 & 0,02797 & 0,02827 \\
& 3 & 0,02855 & \\
$\mathrm{~B}$ & 1 & 0,03347 & 0,03309 \\
& 2 & 0,03271 & \\
& 3 & 0,03308 & 0,03067 \\
$\mathrm{C}$ & 1 & 0,03025 & \\
\hline
\end{tabular}


Berdasarkan Tabel 2 di atas menunjukkan bahwa kadar cemaran $\mathrm{Hg}$ dalam sampel deodoran yang beredar di Kota Makassar berada pada range $0,02827-0,03309 \mathrm{mg} / \mathrm{kg}$.

\section{Pembahasan}

Ada beberapa deodoran yang mempromosikan produknya bisa memutihkan kulit ketiak setelah digunakan beberapa waktu. Produk seperti ini perlu diwaspadai, mengingat efek merkuri yang bersifat akumulasi yang akan mengakibatkan keracunan sistemik jika digunakan dalam jangka panjang. Meskipun efeknya belum akan terasa dalam hitugan hari, akibatnya kerap kali konsumen tidak merasakan efek samping yang merugikan ini (Syafnir dan Putri, 2008)

Berdasarkan hasil penelitian Syafnir dan Putri (2008), menunjukkan bahwa mayoritas responden yang menggunakan kosmetik pemutih tidak mengetahui tentang keberadaan logam merkuri dalam sediaan kosmetik, dan yang lebih parahnya lagi mayoritas responden tersebut tidak mengetahui bahaya dari keberadaan merkuri tersebut dalam kosmetik.

Dalam peraturan kepala Badan Pengawas Obat dan Makanan Republik Indoensia Nomor HK.03.1.23.07.11.6662 tahun 2011, disebutkan bahwa logam $\mathrm{Hg}$ merupakan sesepora (trace element) yang tidak bisa dihindarkan dalam produk kosmetik. Namun dalam peraturan ini disebutkan bahwa persyaratan cemaran merkuri dalam kosmetika tidak lebih dari 1 $\mathrm{mg} / \mathrm{kg}$ atau $1 \mathrm{mg} / \mathrm{L}$ (1 ppm).

Analisis kadar cemaran $\mathrm{Hg}$ dalam sampel deodoran dilakukan dengan metode spektrofotometri serapan atom (SSA). Metode ini dipilih karena realtif sederhana dan memerlukan waktu analisis yang singkat serta sangat sensitif. mengingat jumlah cemaran yang diperbolehkan sangat kecil (maksimum $1 \mathrm{ppm}$ ) sehingga dibutuhkan metode analisis yang sangat sensitif.

Tahapan pertama analisis dilakukan dengan mendestruksi sampel secara basah menggunakan campuran pelarut $\mathrm{HNO}_{3}$ pekat dan $\mathrm{H}_{2} \mathrm{O}_{2}$ (2:1) sebagai zat pengoksidasi.. kemudian hasil destruksi diencerkan dengan air suling dan diukur serapannya dengan SSA menggunakan lampu katoda berongga $\mathrm{Hg}$ pada panjang gelombang $253,7 \mathrm{~nm}$.

Hasil penelitian ini menunjukkan bahwa ke3 sampel deodoran yang dianalisis tercemar logam $\mathrm{Hg}$, yang dapat dibuktikan dengan adanya serapan pada hasil pengukuran larutan sampel dengan SSA menggunakan lampu katoda $\mathrm{Hg}$. Kadar cemaran logam $\mathrm{Hg}$ rata-rata pada masingmasing sampel tersebut adalah sampel A $0,02827 \mathrm{mg} / \mathrm{kg}$, sampel B 0,03309 $\mathrm{mg} / \mathrm{kg}$, dan sampel C 0,03067 mg/kg. Hasil analisis ini menunjukkan bahwa kadar cemaran $\mathrm{Hg}$ dalam ke 3 sampel tersebut masih memenuhi syarat yang telah ditentukan yaitu tidak lebih dari $1 \mathrm{mg} / \mathrm{kg}$ (data selengkapnya lihat Tabel 2).

Umumnya, para pemakai deodoran, terutama kaum wanita, akan menghilangkan bulu/rambut ketiaknya baik dengan cara mencukur ataupun mencabut. Rambut ketiak berfungsi melindungi organ vital kewanitaaan, yaitu payudara. Namun justru kebanyakan kaum wanita berusaha menghilangkan rambut ketiak dengan berbagai alasan.

$\begin{array}{ccc} & \text { Anderson Cancer Centre dalam } \\ \text { Journal } & \text { Inorganic } & \text { Biochemistry }\end{array}$
2005;99(9);1912-1919 dalam Amin, Z (2010) melaporkan bahwa wanita yang mencukur bulu ketiaknya ternyata sepuluh kali lebih rentan terhadap kanker payudara dibandingkan dengan wanita yang membiarkan bulu ketiaknya tumbuh apa adanya. Diungkapkan juga bahwa dengan mencukur bulu ketiak akan timbul luka tak kasat mata serta pori-pori di daerah ketiak akan membesar. Hal ini memungkinkan toksin dan zat-zat kimia aktif dari deodoran dan krim pemutih ketiak akan dengan mudah masuk ke dalam tubuh kita lewat luka-luka dan pori-pori yang membesar. Dengan demikian, adanya cemaran logam $\mathrm{Hg}$ ini dalam sampel deodoran perlu menjadi perhatian masyarakat.

\section{PENUTUP}

\section{Kesimpulan}

Berdasarkan hasil penelitian ini maka dapat disimpulkan bahwa :

1. Tiga sampel deodoran yang dianalisi positif mengandung cemaran logam $\mathrm{Hg}$,

2. Kadar rata-rata cemaran logam $\mathrm{Hg}$ dalam ke 3 sampel yang dianalisis masing-masing adalah sampel A 
$0,02827 \mathrm{mg} / \mathrm{kg}, \quad$ sampel B 0,03309 $\mathrm{mg} / \mathrm{kg}$, dan sampel C $0,03067 \mathrm{mg} / \mathrm{kg}$.

3. Kadar cemaran $\mathrm{Hg}$ dalam ke 3 sampel tersebut masih memenuhi syarat yang telah ditentukan yaitu tidak lebih dari 1 ppm $(1 \mathrm{mg} / \mathrm{kg})$

\section{Saran}

Untuk melengkapi data penelitian ini perlu dilakukan penelitian dengan melakukan analisis cemaran logam berat lainnya ( $\mathrm{Pb}$ dan $\mathrm{As}$ ) dalam deodoran yang beredar di Kota Makassar.

\section{DAFTAR PUSTAKA}

Alfian, Z. 2010. Merkuri: Antara Manfaat dan Efek Penggunaannya Bagi Kesehatan Manusia danLingkungan,(online),(www.usu.ac .id/id/files/pidato/ppgb/2010/ppgb_20 10_zul_alfian.pdf, diakses Juni 2017.

Amin, Y.Z., 2010, Kenali Deodoran Anda, Kliping Humas, Unpad, http://pustaka.unpad.ac.id/wpcontent/uploads/2010/06/pikiranrakyat-20100610kenalideorananda.pdf, diakses Mei 2017

Anonim, 2014, Bahan Ajar Kosmetologi, http://file.upi.edu/Direktori-/FPTK/JUR. PEND. KESEJAHTERAAN KELUARGA-/196310161990012 PIPIN TRESNA PRIHATIN/BU343_KOsmetologi_(Pipin)/bAHAN_ajar_I_Kosmetologi. pdf, diakses 8 Juni 2017

BPOM, 2011, Tentang Persyaratan Cemaran Mikroba Dan Logam Berat Dalam Kosmetika. Peraturan Kepala Badan Pengawas Obat dan Makanan Republik Indonesia Nomor HK.03.1.23.07.11.6662 Tahun 2011
Deviana, N. 2009. Pengetahuan, Sikap dan Tindakan Mahasiswa Mengenai Kosmetik Mengandung Merkuri (Hg) Di Akademi Kebidanan Hafsyah Medan, (online),

(http://repository.usu.ac.id/ bitstream/123456789/14714/1/09E02 160.pdf, diakses 8 Juni 2017.

Diliyana, Y.F. 2012. Studi Kandungan Merkuri (Hg) Pada Ikan Bandeng (Chanos Chanos) Di Tambak Sekitar Perairan Rejoso Kabupaten Pasuruan, (online), lib.uinmalang.ac.id/fullchapter/03520069.p $d f$, diakses 8 Juni 2017

Ginanjar, 2015, Spektrofotometri Serapan Atom, Yogyakarta, PPNY, Batan

Joshita, dan Juhaini,2011, Teknologi Kosmetik, http://staff.ui.ac.id/internal/130674809/material/TEKNO LOGIKOSMETIK.pdf, diakses Mei 2017

Sukanto, H. 2013, Efek Samping Penggunaan Kosmetika, http://isjd.pdii.lipi.go.id/admin/jurnal/ 64951523.pdf, diakses 8 Mei 2017

Supriyadi, 2012, Analisis Logam Kadmium, Timbal, dan krom pada Lipstik secara Spektrofotometri serapan atom. Fak. Farmasi, Universitas Setia Budi Solo

Syahputra, R., 2014, Modul Pelatihan Instrumentasi AAS, Laboratorium Instrumentasi terpadu UII.

Widowati, W., Sastiono, A., dan Juduf, R.R. 2010. Efek Toksik Logam. Andi, Yogyakarta 